THE EFECT OF PROFITABILITY, FIRM SIZE, BOARD OF COMMISSIONERS, LEVERAGE AND MEDIA EXPOSURE TOWARD CORPORATE SOCIAL RESPONSIBILITY DISCLOSURE (CSR) ON THE LISTING AND GO PUBLIC COMPANIES IN INDONESIAN STOCK EXCHANGE (IDX)

\title{
PENGARUH PROFITABILITAS, UKURAN PERUSAHAAN, DEWAN KOMISARIS, LEVERAGE DAN PENGUNGKAPAN MEDIA TERHADAP PENGUNGKAPAN CORPORATE SOCIAL RESPONSIBILITY (CSR) PADA PERUSAHAAN YANG GO PUBLIC DAN LISTING DI BURSA EFEK INDONESIA (BEI)
}

\author{
Oleh: \\ Martha Yurdila J' $\mathbf{J}^{1}$, H. Mukhzarudfa ${ }^{2)}$, Wiralestari ${ }^{3)}$ \\ ${ }^{I}$ Alumni Magister Ilmu Akuntansi Pascasarjana Universitas Jambi Tahun 2019 \\ 2\&3) Dosen Pembimbing \\ Email: ${ }^{1)}$ janur.dila@gmail.com, ${ }^{2)}$ mukhzarudfa.jambi@gmail.com, ${ }^{3)}$ aquarius.ra83@yahoo.com
}

\begin{abstract}
This study aims to determine and analyze the effect of profitability, firm size, board of commissioners, leverage and disclosure of media against disclosure of corporate social responsibility (CSR) on companies that go public and listing on the Indonesia Stock Exchange (IDX) in 2017 for the companies that is publishing annual reports 2013-2017 period. The sample companies in this study were 66 companies after the purposive sampling. The selection of variables in this study is based on the results of previous research journals that show inconsistent results on the factors that influence CSR disclosure. Measurement of corporate social responsibility is based on the categorization of the Global Report Index (GRI) 4 which is seen in the company's annual report.

The sample in this study are companies that go public and listing on the Indonesia Stock Exchange (IDX) in 2017 for the companies that is publishing annual reports 2013-2017 period. The sampling method is using purposive sampling. Profitability is measured based on return on assets (ROA), company size is measured based on total assets, the board of commissioners is measured by the number of commissioners, leverage is measured based on debt to assets ratio (DAR) and media disclosure measured based on CSR activities disclosed on the company's website. The data analysis method used in this study is a classic assumption that uses the hypothesis test of multiple regression linear methods which are processed using SPSS.

The results showed that partially through the $t$ test of profitability did not significantly influence of CSR disclosure while company size, board of commissioners, leverage and media disclosure had a positive and significant effect on the CSR disclosure. Simultaneously through the f test, the results of the study show that profitability, company size, board of commissioners, leverage and media disclosure together influence the disclosure of CSR.
\end{abstract}

Keywords: profitability, company size, board of commissioners, leverage, media disclosure.

\begin{abstract}
ABSTRAK
Penelitian ini bertujuan untuk mengetahui dan menganalisa pengaruh profitabilitas, ukuran perusahaan, dewan komisaris, leverage dan pengungkapan media terhadap pengungkapan corporate social responsibility (CSR) pada perusahaan yang go public dan listing di Bursa Efek Indonesia (BEI) untuk tahun 2017 yang menerbitkan annual reports periode 2013-2017. Perusahaan sample pada penelitian ini adalah sebanyak 66 perusahaan setelah dilakukan purposive sampling. Pemilihan variabel didalam penelitian ini didasarkan atas hasil jurnal-jurnal penelitian terdahulu yang menunjukkan hasil yang inkonsisten terhadap faktor- faktor yang mempengaruhi pengungkapan CSR. Pengukuran dari corporate social responsibility didasarkan pada pengkategorian Global Report Index (GRI) 4 yang terlihat didalam annual reports perusahaan.

Sample didalam penelitian ini adalah perusahaan yang go public dan listing di Bursa Efek Indonesia (BEI) untuk tahun 2017 yang menerbitkan annual reports periode 2013-2017. Metode pengambilan sample adalah menggunakan purposive sampling. Profitabilitas diukur berdasarkan return on asset (ROA), ukuran perusahaan diukur berdasarkan total asset, dewan komisaris diukur berdasarkan banyaknya jumlah anggota dewan komisaris, leverage diukur berdasarkan debt asset to ratio (DAR) dan pengungkapan media diukur berdasarkan kegiatan CSR yang diungkapkan di website perusahaan. Metode analisis data yang digunakan didalam penelitian ini adalah asumsi klasik yang menggunakan uji hipotesis metode regresi linear berganda yang diolah dengan menggunakan SPSS.
\end{abstract}


Hasil penelitian menunjukkan bahwa secara parsial melalui uji t profitabilitas tidak berpengaruh signifikan terhadap pengungkapan CSR sedangkan ukuran perusahaan, dewan komisaris, leverage dan pengungkapan media berpengaruh positif dan signifikan terhadap pengungkapan CSR. Secara simultan melalui uji f didapatkan hasil penelitian bahwa profitabilitas, ukuran perusahaan, dewan komisaris, leverage dan pengungkapan media secara bersama-sama berpengaruh terhadap pengungkapan CSR.

Kata Kunci: profitabilitas, ukuran perusahaan, dewan komisaris, leverage, pengungkapan media. 


\section{PENDAHULUAN}

\subsection{Latar Belakang}

Akuntansi sosial ekonomi merupakan suatu hasil dari upaya untuk mengakomodasi kebutuhan perusahaan dalam melakukan praktik pertanggung jawaban sosial kepada masyarakat. Standar Akuntansi Keuangan (PSAK) No. 1 menyatakan bahwa laporan keuangan yang lengkap terdiri atas neraca, laporan laba rugi, laporan perubahan ekuitas, laporan arus kas dan catatan atas laporan keuangan. Sebagai informasi tambahan pada laporan keuangan, perusahaan diharapkan untuk lebih transparan didalam pengungkapannya. Hal ini bertujuan untuk memudahkan para stakeholders didalam pengambilan keputusan dan berbagai kebijakan. Informasi penting yang pada saat ini disarankan untuk diungkapkan adalah pengungkapan sosial perusahaan (Delena, 2017).

Undang-undang No 40 Tahun 2007 Tentang Perseoran Terbatas Pada BAB V Tanggung Jawab Sosial dan Lingkungan Pasal 74 ayat (1) menyebutkan bahwa perseroan yang menjalankan kegiatan usaha nya di bidang dan/atau berkaitan dengan sumber daya alam wajib melaksanakan tanggung jawab sosial dan lingkungan.

Peraturan Pemerintah Republik Indonesia Nomor 47 Tahun 2012 Tentang Tanggung Jawab Sosial dan Lingkungan Perseroan Terbatas memiliki beberapa point aturan yang berkaitan erat dengan implementasi keuangan berkelanjutan di Indonesia yang terdiri atas pasal-pasal berikut (www.ojk.go.id, 2016):

a. Pasal 2 menyebutkan bahwa setiap perseroan selaku subjek hukum mempunyai tanggung jawab sosial dan lingkungan.

b. Pasal 3 ayat (1) menyebutkan bahwa tanggung jawab sosial dan lingkungan sebagaimana dimaksud dalam pasal 2 menjadi kewajiban bagi perseroan yang menjalankan kegiatan usahanya dibidang dan/atau berkaitan dengan sumber daya alam berdasarkan undang-undang.

Penyimpangan didalam praktik pelaksanaan CSR kerap terjadi demi meningkatkan nilai korporasi dihadapan publik. Hal ini karena concern korporasi hanya sebatas nilai dan brand image sehingga kerap mengabaikan integritas didalam praktik pengungkapan CSR ini. Seperti berita yang dimuat pada lama CNN Indonesia dimana terdapat kasus penyimpangan dana CSR oleh PT. Sumber Alfaria Trijaya Tbk (SAT) yang menggabungkan penggunaan dana donasi dengan laporan tanggung jawab sosial perusahaan (CSR) dalam laporan tahunan perusahaan (annual reports).

Laman berita CNN melaporkan dengan judul “Alfamart Gunakan Donasi untuk CSR Perusahaan". Bunyi putusan Majelis Komisioner yang diketuai oleh Dyah Aryani. P memutuskan bahwa hasil sumbangan harusnya dilaporkan secara terpisah dari laporan CSR termohon (SAT) sesuai dengan UU No. 40/2007 dan PP No. 47/2012. Pada laporan tahunan SAT tentang
CSR pada halaman 126 hingga 129, perusahaan memasukkan penggunaan donasi konsumen sebagai bentuk CSR. SAT menguraikan donasi konsumen dengan pihak-pihak yang menerima. Bunyi putusan KIP mengatakan bahwa seharusnya dalam laporan tahunan 2015 bukan laporan donasi yang dikelola oleh termohon melainkan hasil keuntungan yang disisihkan untuk kegiatan CSR. (Lumbanrau (2016), putusan KIP: alfamart gunakan donasi untuk CSR perusahaan, CNN Indonesia).

Polemik mengenai pertanggung jawaban sosial dan lingkungan kerap juga mewarnai perusahaan sektor pertambangan yang berdiri dan beroperasi di Indonesia, sebut saja PT. Freeport Indonesia yang merupakan perusahaan pertambangan emas terbesar di dunia. Polemik yang terjadi tidak hanya menyangkut kerusakan lingkungan namun juga mengenai masalah sosial-ekonomi masyarakat sekitar. Dikutip dari laman berita merdeka.com dengan tajuk headline "Enaknya Freeport Keruk Emas Papua Tapi Tak Hargai Masyarakat Adat".

Direktur Jenderal Mineral dan Batu Bara (Minerba) Kementerian ESDM, Bambang Gatot Aryono mengakui bahwa PT. Freeport Indonesia selalu dimanja pemerintah sejak dulu. Freeport yang telah mengantongi izin dari tahun 1967 disebut tidak membawa kesejahteraan untuk masyarakat Papua. Sejak Freeport masuk dan berdiri di Timika dan kemudian mengantongi legalitas undang-undang penanaman modal asing (PMA) pertama pada tahun 1967, Freeport tidak pernah melibatkan dan menghargai hak-hak masyarakat adat dua suku besar Amungme dan Kamoro sebagai pemilik hak ulayat. Ketika kesadaran masyarakat adat muncul dengan aksi masyarakat pada tahun 1996 di Timika yang mengorbankan nyawa manusia dan materi barulah dana CSR yang disebut dana satu persen itu diturunkan untuk menutupi pelanggaran yang dilakukan oleh PT. Freeport Indonesia kepada Masyarakat selama sekian tahun.

Pelanggaran-pelanggaran kerusakan lingkungan akibat Iimbah, pelanggaran HAM, konflik sosial dan rusaknya tatanan hidup masyarakat yang sampai saat ini masih dirasakan meninggalkan goresan luka di hati masyarakat adat. (Putra (2017), enaknya freeport keruk emas papua tapi tak hargai masyarakat adat, merdeka.com).

Kasus yang terjadi diatas menggambarkan secara nyata bahwa masih adanya ketidakpedulian perusahaan atas pelaksanaan kegiatan CSR khususnya di Indonesia, bahkan pemerintah Indonesia pun terkesan tidak tegas dalam mengatur praktik pengungkapan CSR tersebut. CSR yang diberikan tidak membuahkan kesejahteraan tetapi hanya menimbulkan konflik internal dikalangan masyarakat karena para elit memanfaatkan hal tersebut untuk kepentingannya sementara masyarakat tidak merasakan dampak dan manfaat dari CSR itu sendiri.

Berita CNN Indonesia menginformasikan bahwa riset temukan kualitas CSR perusahaan Indonesia 
rendah. Riset Centre For Governance, Institution, and Organizations National University of Singapore (NUS) Business School memaparkan rendahnya pemahaman perusahaan terhadap praktik CSR sehingga menyebabkan rendahnya kualitas pengoperasian agenda tersebut. Riset melakukan studi terhadap 100 perusahaan di empat Negara yakni Indonesia, Malaysia, Singapura dan Thailand.

Direktur CGIO National University of Singapore Business School, Lawrence Loh mengatakan empat Negara sampel tersebut adalah yang memiliki tingkat pelaporan CSR yang tinggi, namun tak otomatis membuat kualitas praktinya pun tinggi. Loh mengatakan "Dilihat dari kualitasnya, praktik CSR jauh lebih baik diimplementasikan oleh perusahaanperusahaan di Singapura dan Thailand dibandingkan dengan Indonesia dan Malaysia". Riset tersebut memaparkan Thailand menjadi Negara dengan kualitas implementasi CSR paling tinggi dengan nilai 56,8 dari total 100, sementara Singapura mendapat 48,8. Indonesia dan Malaysia sendiri masing-masing mendapat nilai 48,4 dan 47,7 .

Kriteria penilaian diambil berdasarkan sejumlah indikator dari kerangka Global Reporting Initiative (GRI). Sejumlah faktor diantaranya tata kelola perusahaan, ekonomi, lingkungan, dan sosial. Loh menyatakan, pemerintah dan pemangku kepentingan industri memiliki peran dalam memastikan pelaporan CSR yang berkelanjutan. Hal itu, sambungnya, dinilai sebagai kunci utama tata kelola perusahaan. Hasil studi tersebut dipublikasikan dalam acara Conference on Corporate Governance and Responsibility: Theory Meets Practice, yang digelar oleh NUS dan ASEAN CSR Network (ACN). Konferensi itu bertujuan menghubungkan pelbagai pemangku kepentingan untuk pembangunan berkelanjutan. (Suastha (2016), riset temukan kualitas CSR perusahan Indonesia rendah, CNN Indonesia).

Penelitian yang dilakukan oleh Irwansyah, Ginting, Kusumawardani dan Erdiyanti (2018) melakukan penelitian pengungkapan CSR pada perusahaan yang kegiatan operasional nya berkaitan dengan sumber daya alam, sehingga perusahaanperusahaan tersebut wajib melaksanakan pengungkapan CSR sebagai bentuk tanggung jawab sosial dan lingkungan seperti yang diatur didalam UU No 40 Tahun 2007 Pasal 74 (mandatory). Hasil penelitian menemukan untuk perusahaan yang melaksanakan kegiatan pengungkapan CSR secara mandatory dalam kurun waktu 2012 s/d 2015 menemukan bahwa tingkat pengungkapan CSR yang diukur melalui GRI 3 pada perusahaan-perusahaan tersebut telah mencapai angka persentase rata-rata sebesar $89 \%$. Kesimpulan yang didapat adalah pengungkapan CSR belum terlalu penuh sesuai dengan kriteria GRI 3 namun sudah dapat dikatakan baik.

Merujuk dari penelitian yang dilakukan oleh Irwansyah, Ginting, Kusumawardani \& Erdiyanti (2018) maka peneliti kemudian tertarik untuk melakukan penelitian pada perusahaan-perusahaan sektor jasa dan keuangan, dimana perusahaanperusahaan tersebut dikategorikan sebagai perusahaan yang kegiatan usaha nya tidak berkaitan langsung dengan sumber daya alam, sehingga pengungkapan CSR yang dilakukan bersifat sukarela (voluntary). Peneliti ingin mengetahui seberapa besar tingkat kepedulian perusahaan-perusahaan sample terhadap pelaksanaan kegiatan CSR nya karena tidak diwajibkan oleh peraturan yang berlaku atau tidak bersifat mandatory.

Terdapat beberapa faktor yang secara teoritis dapat mempengaruhi dan mendukung korporasi dalam melakukan pengungkapan CSR. Didalam penelitian ini faktor-faktor yang dipakai adalah beberapa faktor yang telah digunakan para peneliti terdahulu antara lain profitabilitas, ukuran perusahaan, dewan komisaris, leverage dan pengungkapan media.

\subsection{Rumusan Masalah}

Berdasarkan uraian latar belakang diatas, maka rumusan masalah penelitian ini adalah sebagai berikut:

a. Apakah profitabilitas berpengaruh terhadap pengungkapan CSR pada perusahaan yang go public dan listing di Bursa Efek Indonesia (BEI)?

b. Apakah ukuran perusahaan berpengaruh terhadap pengungkapan CSR pada perusahaan yang go public dan listing di Bursa Efek Indonesia (BEI)?

c. Apakah dewan komisaris berpengaruh terhadap pengungkapan CSR pada perusahaan yang go public dan listing di Bursa Efek Indonesia (BEI)?

d. Apakah leverage berpengaruh terhadap pengungkapan CSR pada perusahaan yang go public dan listing di Bursa Efek Indonesia (BEI)?

e. Apakah pengungkapan media berpengaruh terhadap pengungkapan CSR pada perusahaan yang go public dan listing di Bursa Efek Indonesia (BEI)?

f. Apakah profitabilitas, ukuran perusahaan, kepemilikan saham publik, dewan komisaris, leverage dan pengungkapan media secara simultan berpengaruh terhadap pengungkapan CSR pada perusahaan yang go public dan listing di Bursa Efek Indonesia (BEI)?

\section{TINJAUAN PUSTAKA, KERANGAKA PEMIKIRAN DAN HIPOTESIS}

\subsection{Tinjauan Pustaka}

\subsubsection{Corporate Social Responsibility (CSR)}

Keinert (2008:39) mendefinisikan CSR sebagai suatu gagasan yang bertujuan untuk menggambarkan hubungan diantara bisnis dan masyarakat disekitarnya secara luas dan untuk mendefinisikan kembali peran dan kewajiban bisnis swasta didalam masyarakat, jika dianggap perlu. Operasi bisnis tidak diragukan lagi kaitannya dengan kelompok dan aliansi yang lebih besar daripada perusahaan bisnis itu sendiri, mengingat kekuatan luar biasa yang dipraktekkan pada masyarakat kontemporer dilihat dari perpektif politik, ekonomi dan sosial. CSR didorong kebutuhan untuk memasukkan 
kepedulian sosial dan lingkungan ke dalam keputusan dan operasi bisnis dan untuk meningkatkan interaksi dengan para pemangku kepentingan.

Crowter \& Aras (2008:10) mendefinisikan CSR adalah hubungan diantara perusahaan global, pemerintah pada suatu negara dan warga Negara. Secara sederhana pengertian CSR terfokus pada hubungan diantara perusahaan dan masyarakat lokal dimana perusahaan tersebut berdiri dan beroperasi. Pengertian CSR lainnya adalah hubungan antara perusahaan dan para pemangku kepentingan. Crowter \& Aras (2008:11) juga merangkum pengertian CSR menurut EU Commission adalah suatu konsep dimana perusahaan mengintegrasikan kepedulian sosial dan lingkungan dalam operasi bisnis mereka dan berinteraksi dengan para stakeholders secara sukarela.

\subsubsection{Prinsip-prinsip Pelaksanaan CSR}

Terdapat 3 prinsip dasar pelaksanaan kegiatan CSR menurut Crowther \& Aras (2008:14-16), antara lain adalah sebagai berikut:

\section{a) Sustainability (Keberlanjutan)}

Ini difokuskan dengan efek dari tindakan yang diambil pada masa sekarang berdasarkan atas pilihan di masa mendatang. Yang menjadi perhatian khusus adalah sumber daya digunakan pada masa sekarang kemudian tidak lagi tersedia untuk digunakan dimasa mendatang. Ukuran keberlanjutan akan mempertimbangkan tingkat dimana sumber daya dikonsumsi oleh organisasi dalam kaitannya dengan tingkat dimana sumber daya dapat diregenerasi.

b) Accountability (Dapat dipertanggung jawabkan)

Ini difokuskan dengan mengenali suatu organisasi yang tindakannya mempengaruhi lingkungan eksternal dan oleh karena itu memperkirakan tanggung jawab untuk efek dari tindakannya. Konsep ini menekankan hitungan dari efek atas tindakan yang diambil diantara internal organisasi dan externalnya.

c) Transparancy (Transparansi)

Transparansi sebagai dasar, maksudnya adalah dampak eksternal dari tindakan organisasi dapat dipastikan dari laporan organisasi dan fakta yang relevan tidak disamarkan dari yang dilaporkan.

\subsubsection{Peranan dan Manfaat CSR}

Coombs \& Holladay (2012:11) menguraikan berbagai manfaat atau keuntungan dari pelaksanan kegiatan CSR untuk perusahaan dan juga masyarakat, antara lain adalah sebagai berikut:

a) Manfaat atau keuntungan CSR untuk perusahaan.

1. CSR dapat membantu menghindari peraturan pemerintah yang berlebihan.

2. Inisiatif CSR dapat meningkatkan legitimasi sosial perusahaan.
3. Tindakan tanggung jawab secara sosial bisa menguntungkan, CSR dapat menciptakan pengingkatan penghematan biaya.

4. CSR dapat meningkatkan reputasi perusahaan.

5. Inisiatif CSR akan menarik bagi beberapa investor.

6. Profil CSR akan menarik konsumen.

7. Motivasi dan identifikasi karyawan dapat ditingkatkan.

8. CSR dapat meningkatkan identitas dan budaya perusahan mereka melalui penguatan nilai dan orientasi lainnya.

9. Diskusi tentang CSR mendorong karyawan untuk berpikir dengan cara baru dan mengembangkan keterampilan baru.

10. Insiatif CSR dapat menarik liputan media yang positif.

11. Lingkungan pemangku kepentingan yang lebih baik akan menguntungkan korporasi dengan mengurangi churn.

12. Bermitra dengan organisasi lain dan/atau pihak ketiga untuk berbagai ide dapat meningkatkan kemampuan, kredibilitas, visibilitas, dan reputasi.

b) Manfaat atau keuntungan CSR bagi masyarakat.

1. CSR membantu untuk memperbaiki dampak masalah sosial dan lingkungan yang disebabkan oleh operasi bisnis.

2. CSR meminta korporasi bertanggung jawab atas tindakan mereka.

3. CSR mengarahkan perusahaan untuk menghindari biaya eksternalisasi.

4. Didorongnya dialog dan kemitraan di antara beragam pemangku kepentingan.

5. Program CSR mendorong perusahaan untuk melihat perspektif yang lebih luas.

6. Inisiatif CSR yang sukses mengarahkan perusahaan lain untuk meniru inisiatif tersebut.

7. CSR berkontribusi pada keadilan sosial.

8. CSR dapat melengkapi program pemerintah dan kesejahteraan sosial untuk meningkatkan kepedulian sosial dan lingkungan.

\subsubsection{Landasan Teoritis CSR}

Penelitian yang dilakukan oleh Ayman (2017) mengungkapkan terdapat 4 teori yang mendasari teori CSR, diantaranya adalah: 
a) Agency Theory (Teori Agensi)

b) Teori ini menjelaskan tentang hubungan kerja antara pemilik perusahan yang dalam hal ini pemegang saham dan manajemen. Teori agensi muncul ketika pemegang saham mempekerjakan pihak lain dalam mengelola perusahaan yang dimilikinya. Teori agensi melakukan pemisahan terhadap pemegang saham (prinsipal) dengan manajemen (agen). Teori ini menyatakan bahwa perusahaan lebih cenderung menyediakan lebih banyak informasi sukarela untuk mengurangi biaya agensi yang berasal dari konflik antara kepentingan agen dan kepentingan prinsipal. Dengan kata lain, teori agensi berusaha untuk mengurangi konflik agensi antara stakeholders dan manajer dengan menyelaraskan kepentingan manajer (agen) dengan pemegang saham (prinsipal).

c) Managerial Signaling Theory (Teori Signaling Manajerial)

d) Teori ini berpendapat bahwa orang dalam memiliki informasi yang lebih tepat daripada mereka yang berada di luar dan yang memberi mereka keuntungan untuk memprediksi masa depan. Untuk mengurangi asimetri informasi antara orang dalam dan orang luar, perusahaan diharapkan untuk mengadopsi sistem CG yang baik. Selain itu, pengungkapan sukarela yang lebih besar mengurangi masalah informasi antara perusahaan dan investor, sehingga ini dapat membantu untuk membuat peluang investasi yang lebih baik.

e) Stakeholder Theory (Teori Stakeholder)

f) Teori stakeholder adalah teori manajemen organisasi dan etika bisnis yang membahas moral dan nilai-nilai dalam mengelola organisasi, seperti yang terkait dengan tanggung jawab sosial perusahaan, ekonomi pasar dan lainnya. Ada tiga asumsi yang mendasari teori stakeholder. Pertama, perusahaan harus dioperasikan tidak hanya untuk keuntungan finansial dari pemilik saham mereka, tetapi juga untuk memuaskan semua pemangku kepentingan. Kedua, manajer sama-sama bertanggung jawab kepada semua pemangku kepentingan, tidak hanya pemegang saham perusahaan, tetapi juga pemangku kepentingan perusahaan lainnya, seperti karyawan, pemerintah, komunitas lokal, pelanggan, dan pemasok. Ketiga, teori stakeholder didasarkan pada etika organisasi dan sangat terkait dengan CSR perusahaan.

g) Stewardship Theory (Teori Pelayanan)

h) Teori ini berdiri atas asumsi mengenai sifat manusia yang pada hakikatnya dapat dipercaya, mampu bertindak dengan penuh tanggung jawab, memiliki integritas dan kejujuran terhadap pihak lain. Teori ini menggambarkan situasi dimana manajemen tidaklah termotivasi oleh tujuan-tujuan individu tetapi lebih ditujukan pada sasaran hasil utama mereka pada kepentingan organisasi, sehingga teori ini mempunyai dasar psikologi dan sosiologi yang telah dirancang dimana para eksekutif sebagai stewards yang termotivasi untuk bertindak sesuai keinginan prinsipal, selain itu perilaku stewards tdiak akan meninggalkan organisasinya dan berusaha mencapai sasaran organisasi.

\subsubsection{Faktor-Faktor Yang Mempengaruhi Pengungkapan CSR.}

a) Profitabilitas.

Profitabilitas adalah kemampuan dari suatu entitas bisnis untuk memperoleh laba. Laba adalah sisa dari pendapatan yang dihasilkan oleh bisnis setelah membayar semua pengeluaran yang terkait langsung dengan pendapatan, seperti memproduksi produk, dan pengeluaran lain yang terkait dengan pelaksanaan kegiatan bisnis.

b) Ukuran Perusahaan

Ukuran perusahaan adalah salah satu faktor penentu dalam pencapaian efisiensi dalam operasi suatu entitas bisnis. Perusahaan-perusahaan dengan ukuran yang berbeda, masing-masing berusaha berkembang tergantung pada sumber daya dan potensi bisnisnya. Namun, tidak semua entitas bisnis dapat beroperasi dengan efisiensi yang sama. Ukuran perusahaan merupakan suatu skala yang memiliki fungsi untuk mengkategorikan besar kecilnya suatu entitas bisnis (Kurnianingsih \& Heni, 2013).

c) Dewan Komisaris

Dewan komisaris merupakan organ terpenting didalam tubuh perusahaan yang memiliki tugas untuk melakukan pengawasan secara umum dan/atau khusus, sesuai dengan undang-undang (Cahyani \& Suryaningsih, 2016). Dewan komisari dapat dianggap sebagai salah satu bentuk mekanisme untuk mengawasi dan memberikan petunjuk serta arahan kepada manajemen (Restu, Yuliandri, \& Nurbaiti, 2017). Untuk menentukan apakah manajemen sudah secara keseluruhan memenuhi tanggung jawab mereka didalam mengembangkan dan menyelengarakan pengendalian internal perusahaan dan untuk menciptakan tata kelola perusahaan yang baik maka dewan komisaris bertanggung jawab dalam menentukan hal ini sebagai wakil dari para pemangku kepentingan.

\section{d) Leverage}

Leverage sebagai istilah bisnis yang mengacu kepada utang atau meminjam dana untuk membiayai pembelian persediaan, peralatan dan asset perusahaan. Pemilik bisnis dapat menggunakan hutang atau ekuitas untuk membiayai atau membeli asset perusahaan. Meminjam untuk melakukan ekspansi atau berinvestasi disebut leverage karena tujuannya adalah untuk memperkuat pinjaman menjadi nilai yang lebih besar bagi perusahaan atau investor. (Hargrave, 2019). Leverage menunjukkan seberapa besar perusahaan bergantung pada kreditur dalam membiayai asset yang dimiliki (Wahyuningsih \& Mahdar, 2018). 


\section{e) Pengungkapan Media}

Media diperlukan untuk pemenuhan kebutuhan para pemangku kepentingan dan untuk meningkatkan kepercayaan perusahaan dimata publik sebagai bentuk pertanggung jawaban sosial yang fungsi sebagai sarana untuk berkomunikasi secara efektif. Melalui media maka reputasi perusahaan dapat meningkat. Berdasarkan atas teori legitimasi, media memainkan peranan sebagai suatu pressure level yang disebabkan oleh tuntutan publik terhadap perusahaan (Nur \& Priantinah, 2012).

\subsection{Kerangka Pemikiran}

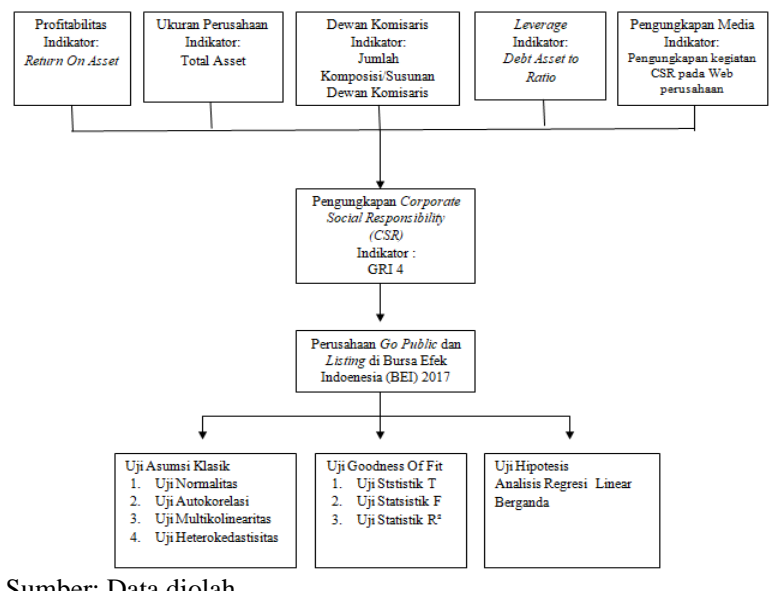

Sumber: Data diolah

Gambar 1. Kerangka Pemikiran Menunjukkan hubungan antara variable independent profitabilitas, ukuran perusahaaan, dewan komisaris, leverage dan pengungkpan media) dengan variable dependen (CSR)

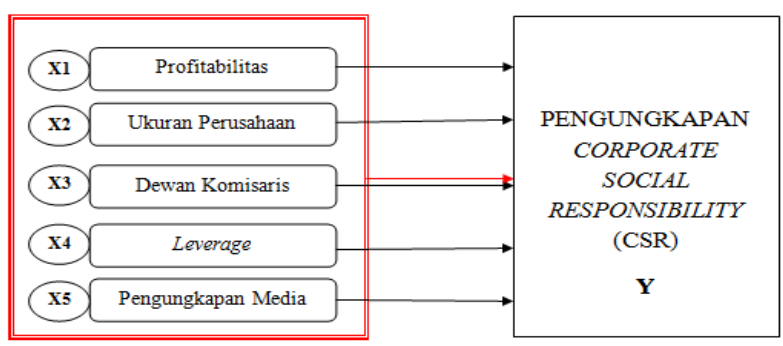

Sumber: Data diolah

\section{Gambar 2. Model Penelitian}

\subsection{Hipotesis Penelitian}

Adapun hipotesis yang diajukan dalam penelitian ini adalah:

a. H1:Profitabilitas berpengaruh terhadap pengungkapan CSR perusahaan.

b. H2:Ukuran perusahaan berpengaruh terhadap pengungkapan CSR perusahaan.

c. H3:Dewan komisaris berpengaruh terhadap pengungkapan CSR perusahaan.

d. H4:Leverage berpengaruh terhadap pengungkapan CSR perusahaan. e. H5:Pengungkapan Media berpengaruh terhadap pengungkapan CSR perusahaan.

f. H6:Profitabilitas, Ukuran Perusahaan, Dewan Komisaris, Leverage dan Pengungkapan Media secara bersama-sama berpengaruh terhadap pengungkapan CSR perusahaan.

\section{METODE PENELITIAN}

\subsection{Populasi dan Sampel}

Populasi dari penelitian ini adalah perusahaan yang go public dan listing dan terindeks pada Bursa Efek Indonesia ( BEI) tahun 2017 sebanyak 66 perusahaan setelah dilakukan purposive sampling memenuhi kriteria sebagai sample penelitian.

\subsection{Definisi Operasional Variabel}

a. Profitabilitas (X1)

Kemampuan perusahaan untuk menghasilkan laba atau profit (Wahyuningsih \& Mahdar, 2018).

\section{ROA = Laba Bersih Setelah Pajak/Total Aktiva}

b. Ukuran Perusahaan (X2)

Suatu skala yang berfungsi untuk mengklasifikasikan besar kecilnya entitas bisnis (Kurnianingsih \& Heni, 2013).

\section{Firm Size $=$ ln $($ Total Aktiva $)$}

c. Dewan Komisaris (X3)

Suatu mekanisme dan badan tertinggi didalam struktur perusahaan dibawah RUPS yang bertugas untuk mengawasi dan memberikan petunjuk, arahan kepada pihak manajemen (Restu et al., 2017).

DK $=\sum$ Dewan komisaris

\section{d. Leverage (X4)}

Tingkat ketergantungan perusahaan terhadap hutang atau meminjam dana untuk membiayai aktivitas operasi perusahaan (Wahyuningsih \& Mahdar, 2018).

\section{DAR = Total Liabilitas/Total Aset}

\section{e. Pengungkapan Media (X5)}

Media adalah sumber utama dari informasi tanggung jawab suatu entitas (Reverte, 2008).

Dummy (1 untuk perusahaan yang mengungkapan kegiatan CSR pada website perusahaan, 0 untuk perusahaan yang tidak mengungkapkan kegiatan CSR pada website perusahaan).

\section{f. Pengungkapan Corporate Social Responsibility (Y)}

CSR adalah tindakan sukarela yang diterapkan oleh perusahaan saat mengejar misinya dan memenuhi kewajiban kepada para pemangku kepentingan, termasuk karyawan, komunitas, lingkungan dan masyarakat secara keseluruhan (Coombs \& Holladay, 2012:8). 


\section{CSRD $=$ V/91 $($ GRI 4)}

\subsection{Sumber Data dan Alat Pengumpulan Data}

Penelitian ini menggunakan data sekunder dari perusahaan yang go public dan listing di Bursa Efek Indonesia yang terindeks pada tahun 2017 (www.idx.co.id). Data yang digunakan adalah annual reports perusahaan periode 2013- 2017, serta website perusahaan, dengan teknik pengumpulan data dokumentasi.

\subsection{Teknik Analisis Data}

Metode analisis data dalam penelitian ini menggunakan model regresi linier berganda (multiple linear regression). Analisis regresi linear berganda adalah hubungan secara linear antara dua atau lebih variabel penelitian yaitu variabel independen dengan variabel dependen. Analisis ini dilakukan didalam penelitian ini untuk mengetahui ada atau tidaknya pengaruh profitabilitas, ukuran perusahaan, ukuran dewan komisaris, leverage dan pengungkapan media terhadap praktik pengungkapan CSR suatu perusahaan yang listing dan go public di Bursa Efek Indonesia. Untuk pengungkapan media dilakukan dengan cara dummy. Regresi berganda variabel dummy bertujuan untuk memprediksi besar variabel dependen menggunakan variabel independen, dimana data dependen (Y) adalah kuantitatif (pengungkapan CSR) dan data independen (X) adalah merupakan data kategorikal (adanya pengungkapan CSR pada website perusahaan $=1$ dan tidak adanya pengungkapan CSR pada website perusahaan $=0$ ), sehingga dapat diperoleh model persamaan nya adalah sebagai berikut:

$$
\mathrm{Y}=\alpha+\beta 1 \mathrm{X} 1+\beta 2 \mathrm{X} 2+\beta 3 \mathrm{X} 3+\beta 4 \mathrm{X} 4+
$$
$\beta 5 d X 5 d+\varepsilon$.

Dimana:
$\begin{aligned} \mathrm{Y}= & \text { Indeks pengungkapan CSR suatu } \\ & \text { perusahaan } \\ \alpha= & \text { Konstanta/Intersep Model } \\ \beta= & \text { Koefisien Regresi Model } \\ \mathrm{X} 1= & \text { Profitabilitas } \\ \mathrm{X} 2= & \text { Ukuran Perusahaan } \\ \mathrm{X} 3= & \text { Dewan Komisaris } \\ \mathrm{X} 4= & \text { Leverage } \\ \mathrm{X} 5= & \text { Pengungkapan Media (dalam dummy) } \\ \varepsilon= & \text { Error Term Model (variabel residual) }\end{aligned}$

\section{HASIL DAN PEMBAHASAN}

\subsection{Hasil Penelitian}

Berikut dibawah ini adalah uraian mengenai hasil penelitian yang merupakan output dari SPSS Statistic 25 dan diolah dengan menggunakan analisis regresi linear berganda: a. Statistik Deskriptif

\section{Tabel 1. Statistik Deskriptif}

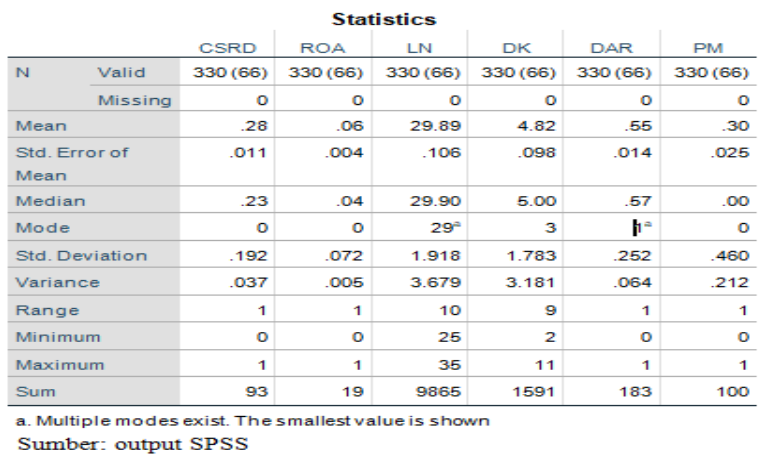

Tabel 1 di atas menunjukkan bahwa variabel dependen yaitu pengungkapan corporate social responsibility (CSRD) mempunyai nilai rata-rata (mean) dari 66 perusahaan sample adalah 0,28 atau 28 $\%$, nilai tengah (median) adalah 0,2300 , nilai minimum adalah 0 , nilai maksimum adalah 1 dan nilai standar deviasi adalah 0,192 atau 19,2\%. Variabel independen profitabilitas yang diproksikan dengan ROA menunjukkan nilai rata-rata (mean) adalah 0,06 atau 6 $\%$, nilai tengah (median) adalah 0,04 atau $4 \%$, nilai minimum adalah 0 , nilai maximum adalah 1 dan nilai standar deviasi adalah 0,072 atau 7,2 \% . Variabel independen ukuran perusahaan yang diproksikan dengan $\ln$ (asset) diketahui mempunyai nilai rata-rata (mean) adalah 29,89 atau $2.989 \%$, nilai tengah (median) adalah 29,90 atau $2.990 \%$, nilai minimum adalah 25, maximum adalah 35 dan nilai standar deviasi adalah 1,918 atau $191,8 \%$. Variabel independen dewan komisaris yang diproksikan dengan jumlah dewan komisaris (DK) menunjukkan nilai ratarata (mean) adalah 4,82 atau $482 \%$, nilai tengah (median) adalah 5,00 atau $500 \%$, nilai minimum adalah 2, nilai maksimum adalah 11 dan nilai standar deviasinya adalah 1,783 atau $188,3 \%$. Variabel independen leverage yang diproksikan dengan Debt to Asset Ratio (DAR) menunjukkan nilai rata-rata (mean) adalah 0,55 atau $55 \%$, nilai tengah (median) adalah 0,57 atau $57 \%$, nilai minimal adalah 0 , nilai maksimal adalah 1 dan standar deviasinya adalah 0,252 atau 25,2 $\%$. Variabel pengungkapan media yang dilihat melalui ada atau tidaknya pengungkapan kegiatan CSR pada website perusahaan sample mempunyai nilai rata-rata (mean) adalah 0,30 atau $30 \%$, nilai tengah (median) adalah 0,00 atau $0 \%$, nilai minimum 0 , dan nilai maksimum 1 dan standar deviasinya adalah 0,460 atau $46 \%$.

\section{b. Uji Normalitas}

Berdasarkan tampilan grafik normal P-Plot diatas disimpulkan bahwa pada grafik normal P-Plot terlihat titik-titik menyebar disekitas garis diagonal,serta arah penyebarannya mengikuti arah garis diagonal, hal tersebut menunjukan bahwa model regresi layak dipakai karena memenuhi asumsi normalitas. 


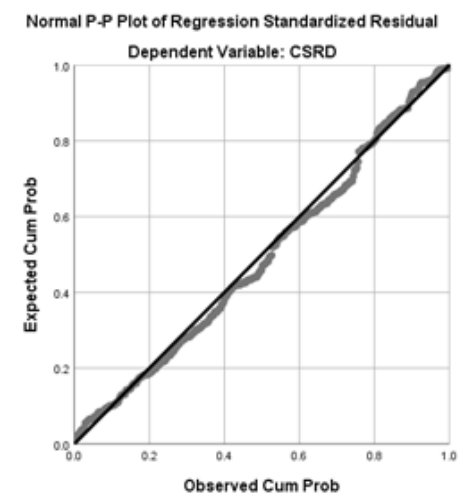

Sumber : Output SPSS

\section{Gambar 3. Grafik Uji Normalitas}

c. Uji Asumsi Klasik

1) Uji Multikolinearitas

Tabel 2. Hasil Uji Multikolinearitas

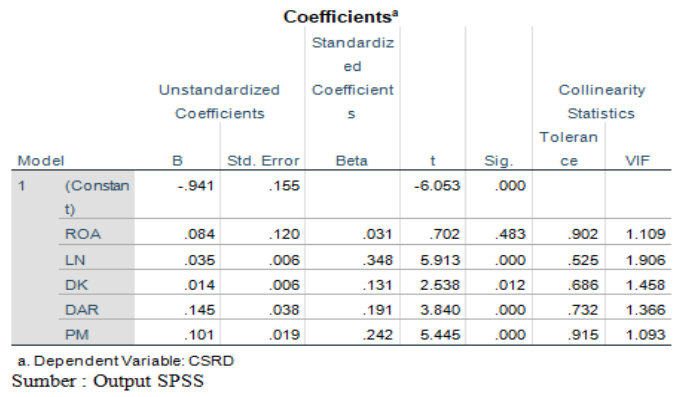

Dari tabel 2 di atas terlihat bahwa semua nilai VIF dari hasil regresi dibawah 10 dan nilai tolerance mendekati 1, sehingga dapat disimpulkan tidak terjadi multikolinearitas.

2) Uji Autokorelasi

Uji autokorelasi dilakukan untuk mengetahui adakah korelasi variable yang ada didalam model prediksi dengan perubahan waktu. Pengujian autokorelasi pada penelitian ini menggunakan statistik uji Durbin Watson. Berdasarkan analisa yang dilakukan, maka diperoleh nilai Durbin Watson 1,459. Dengan demikian Durbin Watson berada diantara nilai 12 yang berarti tidak ada autokorelasi.

Tabel 3. Hasil Uji Autokorelasi

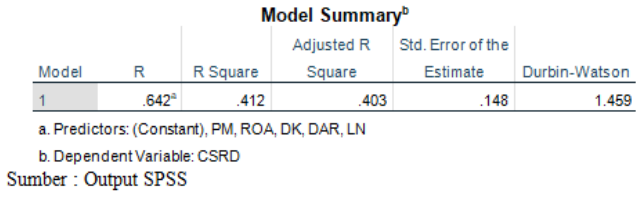

3) Uji Heterokedastisitas

Uji heterokedastisitas adalah uji yang dilakukan untuk menilai apakah ada ketidaksamaan varian dari residual untuk semua pengamatan pada model regresi linear. Uji scatterplot dilakukan untuk mendeteksi ada atau tidaknya heterokedastisitas. Hasilnya dapat dilihat pada gambar 4 yang menunjukkan bahwa dari grafik scatterplot tersebut, dapat diketahui bahwa titik data menyebar secara acak serta tersebar diatas maupun dibawah angka 0 pada sumbu Y. Hal ini berarti tidak terjadi heterokedastisitas pada model regresi didalam penelitian ini.

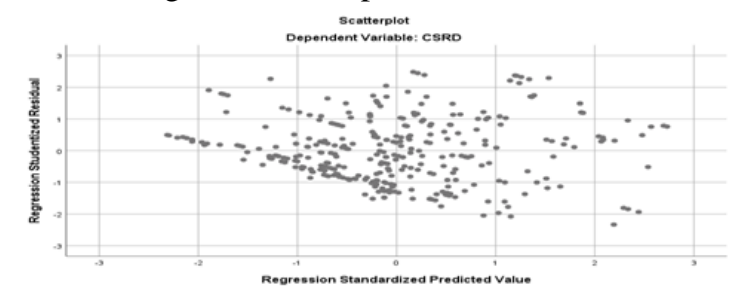

Sumber : Output SPSS

Gambar 4. Grafik Scatterplot

d. Pengujian Hipotesis

1) Analisis Regresi Linear Berganda

Analisis regresi linear berganda dilakukan untuk mengetahui ada atau tidaknya pengaruh antara variabel independen dengan variabel dependen. Dengan demikian persamaan regresi yang digunakan adalah $\mathrm{Y}=\alpha+\beta 1 \mathrm{X} 1+\beta 2 \mathrm{X} 2+\beta 3 \mathrm{X} 3$ $+\beta 4 X 4+\beta 5 d X 5 d+\varepsilon$. Dari analisis regresi linear dengan menggunakan program SPSS diperoleh hasil seperti dalam tabel 3. Berdasarkan tabel 4, persamaan regresi yang dapat disusun adalah CSRD $=-0,941+0,084$ Profitabilitas $+0,035$ Ukuran Perusahaan + 0,014 Dewan Komisaris + 0,145 Leverage + 0,101 Pengungkapan Media + $\varepsilon$.

Tabel 4. Hasil Analisis Regresi Berganda

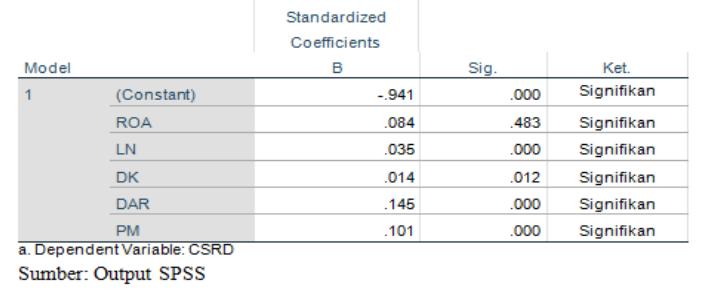

2) Pengujian Goodness Of Fit

a) Uji Statistik $\mathrm{T}$ (Parsial)

Uji statistik $\mathrm{t}$ dilakukan untuk menyelidiki lebih lanjut mana diantara dua atau lebih variabel independen yang berpengaruh signifikan terhadap variabel dependen. Uji satatistik $\mathrm{t}$ dilakukan dengan melihat nilai signifikansi yang diperoleh masing-masing variabel. Hasil pengujian menunjukkan sebagai berikut:

- ROA (X1) memiliki tingkatan Sig. 0,483 lebih besar dari taraf signifikansi 0,05 (5\%). Maka diperoleh hasil bahwa Ho 
diterima dan Ha ditolak. Hal ini menunjukkan bahwa profitabilitas tidak terbukti berpengaruh signifikan terhadap pengungkapan CSR. Dengan demikian hipotesis pertama (H1) yang menyatakan bahwa profitabilitas berpengaruh terhadap pengungkapan CSR tidak dapat diterima.

- LN (X2) memiliki tingkatan Sig. 0,000 lebih kecil dari taraf signifikansi 0,05 (5\%). Maka diperoleh hasil bahwa Ho ditolak dan Ha diterima. Hal ini menunjukkan bahwa ukuran perusahaan terbukti berpengaruh positif dan signifikan terhadap pengungkapan CSR. Dengan demikian hipotesis kedua (H2) yang menyatakan bahwa ukuran perusahaan berpengaruh terhadap pengungkapan CSR dapat diterima.

- DK (X3) memiliki tingkatan Sig. 0,012 lebih kecil dari taraf signifikansi 0,05 (5\%). Maka diperoleh hasil bahwa Ho ditolak dan $\mathrm{Ha}$ diterima. Hal ini menunjukkan bahwa dewan komisaris terbukti berpengaruh positif dan signifikan terhadap pengungkapan CSR. Dengan demikian hipotesis ketiga (H3) yang menyatakan bahwa dewan komisaris berpengaruh terhadap pengungkapan CSR dapat diterima.

- DER (X4) memiliki tingkatan Sig. 0,000 lebih kecil dari taraf signifikansi 0,05 (5\%). Maka diperoleh hasil bahwa Ho ditolak dan $\mathrm{Ha}$ diterima. Hal ini menunjukkan bahwa leverage terbukti berpengaruh positif dan signifikan terhadap pengungkapan CSR. Dengan demikian hipotesis keempat (H4) yang menyatakan bahwa leverage berpengaruh terhadap pengungkapan CSR dapat diterima.

- PM (X5) memiliki tingkatan Sig. 0,000 lebih kecil dari taraf signifikansi 0,05 (5\%). Maka diperoleh hasil bahwa Ho ditolak dan $\mathrm{Ha}$ diterima. Hal ini menunjukkan bahwa pengungkapan media terbukti berpengaruh positif dan signifikan terhadap pengungkapan CSR. Dengan demikian hipotesis kelima (H4) yang menyatakan bahwa pengungkapan media berpengaruh terhadap pengungkapan CSR dapat diterima.

b) Uji Statistik F (Simultan)

Uji statistik f dilakukan untuk melihat apakah variabel independen penelitian secara serentak atau bersama-sama berpengaruh terhadap variabel dependen. Dari pengujian regresi dengan melihat tabel Anova, diketahui $p$-value sebesar $0,000<$ alpha 0,05 maka Ho ditolak dan Ha diterima. Artinya jika diuji secara simultan maka seluruh variabel independen yaitu profitabilitas, ukuran perusahaan, dewan komisaris, leverage dan pengungkapan media secara bersama-sama mempengaruhi pengungkapan corporate social responsibility (CSR) pada perusahaan yang go public dan listing di BEI dalam kurun waktu 2013-2017, dengan demikian hipotesis keenam (H6) dapat diterima. Hasil pengujian regresi dapat dilihat melalui tabel 5 berikut:

Tabel 5. Hasil Uji Statistik F

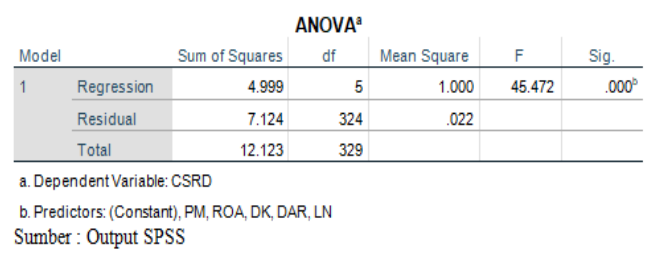

c) Uji Statistik Koefisien Determinasi $\left(\mathrm{R}^{2}\right)$

Dalam uji regresi linear berganda ini dianalisis pula besarnya koefisien determinasi $\left(\mathrm{R}^{2}\right)$. Uji koefisien determinasi dalam penelitian ini digunakan untuk melihat besarnya pengaruh variabel independen (profitabilitas, ukuran perusahaan, dewan komisaris, leverage dan pengungkapan media) terhadap variabel dependen (pengungkapan CSR). Hasil pengujian menunjukkan $\mathrm{R}^{2}$ sebesar 0,403 atau $40,30 \%$ sehingga dapat dikatakan bahwa $40,30 \%$ besarnya pengungkapan CSR perusahaan yang go public dan listing di Bursa Efek Indonesia (BEI) disebabkan oleh profitabilitas, ukuran perusahaan, dewan komisaris, leverage dan pengungkapan media dapan dijelaskan. Sedangkan 59,70\% besarnya pengungkapan CSR disebabkan oleh variabel-variabel lain yang tidak diteliti dalam penelitian ini. Hasil uji statistic koefisien determinasi $\left(\mathrm{R}^{2}\right)$ dapat dilihat dalam tabel 6 berikut:

Tabel 6. Hasil Statistik Koefisien Determinasi $\left(\mathbf{R}^{2}\right)$

\begin{tabular}{llll} 
Model & \multicolumn{2}{c}{ R Square } & \multicolumn{2}{c}{ Adjusted R Square } \\
\hline 1 & $.642^{2}$ & .412 & .403 \\
\hline $\begin{array}{l}\text { a. Predictors: (Constant), PM, ROA, DK, DAR, LN } \\
\text { b. Dependent Variable: CSRD }\end{array}$ & & \\
Sumber : Output SPSS & & &
\end{tabular}

\section{HASIL DAN PEMBAHASAN}

\subsection{Profitabilitas Terhadap Pengungkapan CSR}

Hasil penelitian profitabilitas yang diproksikan dengan ROA menunjukkan pengaruh yang tidak signifikan terhadap pengungkapan CSR dengan nilai signifikansi 0,483 atau profitabilitas diatas 5\%. Ini 
berarti bahwa besar kecilnya profitabilitas tidak akan mempengaruhi tingkat pengungkapan CSR maka hipotesis penelitian ditolak. Hasil penelitian ini mendukung penelitian yang dilakukan oleh Kurnianingsih \& Heni (2013) yang melakukan penelitian pada perusahaan perbankan yang listing di BEI, Farman (2018) dengan subjek penelitian nya adalah perusahaan pertambangan yang listing di BEI, dimana profitabilitas berpengaruh negatif terhadap pengungkapan CSR. Hal ini disebabkan adanya anggapan bahwa kegiatan CSR hanya akan menambah biaya bukan menambah nilai sehingga hanya akan mengurangi laba yang telah diperoleh perusahaan.

Hasil penelitian ini tidak sejalan dengan hasil penelitian yang dilakukan oleh Ompusunggu (2016) yang kembali melakukan penelitian pada perusahaan pertambangan yang listing di BEI, dimana profitabilitas berpengaruh positif dan signifikan terhadap pengungkapan CSR yang menyatakan bahwa semakin tinggi tingkat profitabilitas maka akan semakin luas pula pengungkapan CSR yang dilakukan.

Penelitian yang dilakukan oleh Irwansyah, Ginting, Kusumawardani \& Erdiyanti (2018) dengan subjek penelitian nya perusahaan yang listing di BEI periode 2012-2015 menemukan bahwa profitabilitas berpengaruh terhadap pengungkapan CSR dan mendukung teori stakeholder yang menyatakan bahwa semakin tinggi tingkat profitabilitas yang dicapai oleh perusahaan, semakin kuat hubungan pengungkapan social perusahaan. Ini berarti tingkat keuntungan yang tinggi dapat mendorong perusahaan untuk menerapkan dan mengungkapkan kegiatan CSR sehingga dapat meningkatkan reputasi perusahaan.

Alasan lain yang dapat dijelaskan dari hasil penelitian bahwa profitabilitas tidak berpengaruh terhadap pengungkapan CSR adalah bahwa perusahaan-perusahaan sample mungkin saja merasakan tidak perlu melakukan pengungkapan CSR ketika memperoleh laba yang tinggi karena perusahaan tersebut bukanlah dapat dikategorikan ke dalam perusahaan yang melakukan kegiatan operasional yang secara langsung bersentuhan dengan alam sehingga tidak memiliki dampak yang buruk secara langsung terhadap sosial dan lingkungan atau dengan kata lain bukan termasuk perusahaan yang dikategorikan menurut UU No. 40 Tahun 2007 dan PP No. 47 Tahun 2017, sehingga manajemen beranggapan bahwa praktik pengungkapan CSR bukan merupakan suatu kewajiban, melainkan merupakan suatu kesukarelaan.

\subsection{Ukuran Perusahaan Terhadap Pengungkapan CSR}

Ukuran perusahaan yang diukur dengan total asset berpengaruh positif dan signifikan terhadap pengungkapan CSR dengan nilai signifikansi 0,000 atau ukuran perusahaan dibawah $5 \%$ maka hipotesis penelitian diterima. Hasil penelitian ini menggambarkan bahwa semakin banyak jumlah asset maka akan semakin banyak pengungkapan CSR yang akan dilakukan oleh perusahaan.
Hasil penelitian ini mendukung penelitian yang dilakukan oleh Dewanti \& Widyadmono (2018) dengan sample penelitian 89 perusahaan yang listing di BEI periode 2009-2012. Hasil penelitian menjelaskan bahwa ukuran perusahaan mempengaruhi kegiatan CSR suatu perusahaan karena perusahaan yang besar akan memiliki sumber daya keuangan yang baik dan cukup untuk memulai proyek CSR mereka.

Penelitian yang dilakukan Kurnianingsih \& Heni (2013), Laksmitaningrum \& Purwanto (2013), Ehije dan Ofonson (2013), Cahyani \& Suryaningsih (2016), menemukan bahwa besar atau kecilnya ukuran perusahaan tidak berpengaruh terhadap pengungkapan CSR. Hal ini didukung oleh teori legitimasi yang menyatakan bahwa perusahaan besar tidak akan selalu mengungkapkan informasi sosialnya lebih banyak untuk memberi pengaruh pihak internal maupun external perusahaan. Hal ini dikarenakan perusahaan besar belum menyadari bahwa pengungkapan CSR adalah suatu kebijakan yang efektif untuk memperoleh keuntungan dimasa mendatang.

Hasil penelitian ini menggambarkan bahwa perusahaan-perusahaan sample yang telah go public dan listing di BEI dapat dikategorikan ke dalam perusahaan besar yang cenderung memiliki dampak sosial yang lebih besar pula. Perusahaan go public merupakan emiten bisnis yang banyak disoroti oleh publik. Perusahaan-perusahaan besar tidak akan lepas dari tekanan publik yang berasal dari aktivitas operasi mereka dan juga mempunyai tingkat visibilitas yang tinggi sehingga akan lebih responsive di dalam pelaksanaan kegiatan CSR sebagai bentuk tanggung jawab sosial dan lingkungan atas aktivitas operasional perusahaan.

Perusahaan go public akan lebih besar tingkat resistensi nya yang bisa mengganggu tujuan perusahaan untuk mendapatkan legitimasi dan nilai positif dari masyarakat atau stakeholders lainnya. Jika dikaitkan dengan teori legitimasi, dapat dijelaskan bahwa perusahaan besar yang melakukan lebih banyak aktivitas akan memberikan dampak yang lebih besar pula terhadap masyarakat sehingga pengimplementasian kegiatan CSR dimaksudkan untuk menekan tingkat resistensi yang dikhawatirkan bisa terjadi.

Perusahaan besar biasanya akan memiliki jumlah pemegang saham yang banyak dan beragam dengan latar belakang yang berbeda-beda yang boleh jadi sebagian dari pemegang saham tersebut terkait dengan berbagai program sosial dan lingkungan dan sangat concern terhadap isu-isu mengenai lingkungan yang saat ini marak dipublikasikan oleh banyak aktivis. Dengan demikian berdasarkan atas teori stakeholder yang berfokus kepada cara-cara yang digunakan oleh perusahaa untuk mengelola hubungan perusahaan dengan stakeholder-nya, perusahaan-perusahaan sample dalam penelitian ini sangat menyadari bagaimana kedudukan pengungkapan CSR perusahaan mereka sebagai bentuk representasi atas kepedulian 
perusahaan terhadap isu sosial dan lingkungan tersebut, hal ini dilakukan dengan tujuan untuk membangun kepercayaan stakeholder atas kestabilan keuangan perusahaan juga untuk menarik para investor dan menjaga kestabilan harga saham di pasar modal.

\subsection{Dewan Komisaris Terhadap Pengungkapan CSR}

Hasil penelitian menunjukkan bahwa dewan komisaris berpengaruh signifikan terhadap pengungkapan CSR dengan tingkat signifikansi 0,012 atau dibawah $5 \%$, maka hipotesis penelitian diterima.

Hasil penelitian ini sejalan dengan penelitian yang dilakukan oleh Laksmitaningrum \& Purwanto (2013) dengan sample penelitian nya perusahaan manufaktur yang listing di BEI periode 2009-2011, Wagiu \& Mekel (2014) dengan sample penelitian perusahaan yang terpublish pada Indonesian Capital Market Directory (ICMD) periode 2009-2012, Cahyani \& Suryaningsih (2016) dengan sample penelitian adalah 55 perusahaan manufaktur yang listing di BEI periode 2013-2014, Eriandani \& Kuswanto (2016) dengan sample penelitian nya adalah 795 perusahaan yang listing di BEI periode 2010-2012, Restu, Yuliandri \& Nurbaiti (2017) dengan sample penelitian perusahaan BUMN yang tercatat di BEI tahun 2013-2016.

Penemuan penelitian ini berarti dewan komisaris yang dimiliki oleh perusahaan sample dapat menjalankan peran dan fungsinya. Keberadaan dewan komisaris dalam melakukan pengawasan atas kebijakan pengurusan, jalannya pengurusan pada umumnya, dan memberikan nasihat kepada direksi/manajemen dalam kegiatan operasional perusahaan. Dewan komisaris juga sebagai perwakilan dari para pemegang saham didalam suatu entitas bisnis yang dapat memberikan tekanan kepada manajemen untuk melaksanakan kegiatan yang merupakan mandat dari para pemegang saham, salah satu nya adalah pelaksanaan pengungkapan CSR dengan baik.

Hasil penelitian ini juga mendukung teori agensi yang menyatakan bahwa pemegang saham mengharapkan informasi tingkat tinggi dari dewan komisaris karena mereka telah dipilih untuk mewakili kepentingan para pemegang saham (Ayman, 2017), ini berarti para pemangku kepentingan akan mendelegasikan wewenangan kepada dewan komisaris untuk mengawasi aktivitas manajemen. Teori signaling manajerial yang secara umum menjelaskan bahwa orang dalam memiliki informasi yang lebih tepat daripada mereka yang berada diluar sehingga memberikan keuntungan untuk memprediksi masa depan, orang dalam yang dimaksudkan adalah dewan komisaris sebagai informan yang memberikan informasi kepada para pemangku kepentingan yang dapat digunakan segabai dasar untuk pembuat dan pengambilan mengenai prediksi investasi mereka didalam perusahaan. Salah satu informasi penting yang diharapkan untuk diungkapakan adalah praktik pengungkapan CSR perusahaan sebagai salah satu bentuk etika bisnis yang harus dilakukan demi peningkatan image dan value perusahaan dan kestabilan harga saham di pasar modal.

Teori legitimasi secara umum menjelaskan bahwa komposisi dewan komisaris memberikan pengaruh terhadap pengungkapan CSR perusahaan dimana pengungkapan CSR ini merupakan salah satu perwujudan GCG (good corporate governance) yang diperlukan untuk mendorong terciptanya pasar yang efisien, transparan, dan konsisten dengan peraturan perundang-undangan.

\subsection{Leverage Terhadap Pengungkapan CSR}

Hipotesis keempat yaitu terdapat pengaruh leverage terhadap pengungkapan CSR. Dalam penelitian ini dimana leverage yang diproksi dengan DAR (Debt to Asset Ratio) menunjukkan pengaruh yang signifikan terhadap pengungkapan CSR dengan signifikansi 0,000 maka hipotesis diterima.

Hasil penelitian ini mendukung penelitian yang dilakukan oleh Wahyuningsih \& Mahdar (2018), Irwansyah, Ginting, Kusumawardani \& Erdiyanti (2018) yang menyatakan bahwa perusahaan akan mengekspos image positif kepada para debtholders untuk menciptakan tingkat kemampuan keuangan perusahaan yang baik didalam membayar hutang. Jika penambahan hutang perusahaan dapat meningkatkan laba perusahaan, maka itu akan memberikan sinyal positif kepada investor yang kemudian investor akan tertarik untuk berinvestasi.

Hasil penelitian ini mendukung teori signaling manajerial bahwa investor rasional akan melihat bahwa peningkatan nilai perusahaan berasal dari penggunaan hutang yang digunakan untuk pengembangan aktivitas bisnis perusahaan. Tambahan informasi diperlukan untuk menghilangkan keraguan terhadap dipenuhinya hak-hak kreditur, salah satu informasi tambahan tersebut adalah pengungkapan CSR perusahaan.

Penelitian yang dilakukan oleh Laksmitaningrum \& Purwanto (2013), Cahyani \& Suryaningsih (2016) menemukan bahwa leverage tidak mempengaruhi pengungkapan CSR. Perusahaan dengan tingkat leverage yang tinggi akan membuat perusahaan mengurangi pengungkapan tanggung jawab sosialnya agar tidak menjadi sorotan debtholder. Hal ini dikarenakan hubungan perusahaan yang sudah terjalin baik dengan debtholder membuat debtholder tidak terlalu memperhatikan rasio leverage perusahaan, sehingga menjadikan hubungan leverage dan pengungkapan CSR menjadi tidak signifikan.

Penelitian ini menemukan bawa perusahaan sample adalah perusahaan yang telah go public akan berkompetisi untuk membangun image yang baik dan kepercayaan dimata para debtholders yang akan menunjukkan tingkat kemampuan perusahaan di dalam membayar hutang dengan tujuan untuk kembali mendapatkan obligasi dimasa yang akan datang. Salah satu cara yang dapat dilakukan adalah dengan mengekpos praktik pengungkapan CSR perusahaan. Ini akan memberikan nilai unggul dimana perusahaan yang 
melakukan kegiatan pengungkapan CSR akan lebih cenderung dijadikan mitra yang baik jika dibandingkan dengan perusahaan yang tidak dikenal karena orientasi sosialnya (Keinert, 2008).

\subsection{Pengungkapan Media Terhadap Pengungkapan CSR}

Hasil penelitian ini menunjukkan pengungkapan media berpengaruh signifikan terhadap pengungkapan CSR dengan nilai signifikansi 0,000 maka hipotesis diterima.

Kemudian hasil penelitian ini mendukung penelitian yang dilakukan oleh Jenkins \& Nataila Yakovleva (2006) dengan sample penelitian adalah 10 perusahaan mining terbesar didunia dan Reverte (2008) yang melakukan penelitian pada perusahan-perusahaan yang terdapat di Spanyol menemukan bahwa media memainkan peranan pasif dalam membentuk normanorma sosial kelembagaan dan aktif dalam memilih informasi yang layak dilaporkan dan membingkainya untuk mencerminkan nilai-nilai editorial. Namun hasil penelitian ini berbeda dengan penelitian yang dilakukan oleh Nur \& Priantinah (2012) yang kemudian melakukan penelitian pada perusahaan berkategori high profile yang listing di BEI, menemukan bahwa pengungkapan media tidak berpengaruh terhadap pengungkapan CSR.

Hasil penelitian ini memberikan gambaran bahwa perusahaan-perusahaan sample sangat memanfaatkan website perusahaan sebagai sarana media exposure yang menampilkan seluruh kegiatan mereka. Karena pesatnya penggunaan internet dikalangan masyarakat, pemanfaatan website sebagai media perusahaan untuk mengkomunikasikan program CSR juga menjadi pertimbangan. Media juga mendorong perusahaan untuk meyertakan seluruh kegiatan yang bekenaan dengan aktivitas sosial dan lingkungan perusahaan. Hasil penelitian juga menemukan bahwa para investor atau stakeholder tidak mempunyai waktu yang cukup untuk melihat dan menelusuri isi dari annual report yang disajikan perusahaan dengan jumlah halaman yang begitu banyak, sehingga pengungkapan media mempunyai peranan penting yang secara efektif mampu mempresentasikan profil perusahaan secara general, termasuk didalamnya yang juga menjadi sorotan adalah seluruh kegiatan-kegiatan yang bekenaan dengan praktik CSR perusahaan itu sendiri.

Hasil penelitian ini mendukung teori legitimasi dimana teori ini berfokus kepada interaksi diantara perusahaan dengan bagian dari masyarakat. Teori ini menyatakan bahwa organisasi adalah bagian dari masyarakat sehingga harus memperhatikan normanorma sosial masyarakat. Berdasarkan atas teori ini pengkomunikasian CSR melalui media dapat dilakukan sebagai bagian dari proses membangun institusi, membentuk norma yang diterima dan legitimasi praktik (Reverte, 2008).

Hasil penelitian ini kemudian mendukung adanya teori kontrak sosial diantara perusahaan dan masyarakat karena adanya interelasi diantara kehidupan sosial masyarakat untuk menciptakan keselarasan, keserasian, dan keseimbangan termasuk mengenai masalah lingkungan, sehingga pengungkapan media sangat penting untuk mengungkapkan bentuk-bentuk kegiatan pertanggungjawaban sosial dan lingkungan yang telah dilaksanakan oleh perusaahaan.

\subsection{Profitabilitas, Ukuran Perusahaan, Dewan Komisaris, Leverage dan Pengungkapan Media Terhadap Pengungkapan CSR.}

Hasil penelitian ini menunjukkan bahwa profitabilitas, ukuran perusahaan, dewan komisaris, leverage dan pengungkapan media secara bersamasama berpengaruh signifikan terhadap tingkat pengungkapan CSR maka hipotesis diterima dengan hasil pengujian menunjukkan $\mathrm{R}^{2}$ sebesar 0,403 atau $40,30 \%$. Artinya bahwa varibel independent yang digunakan didalam penelitian ini dapat menjelaskan variabel dependent sebesar 40,30\%. Sedangkan 59,70 $\%$ dijelaskan oleh variabel lainnya yang tidak digunakan didalam penelitian ini.

Pengaruh variabel profitabilitas, ukuran perusahaan, dewan komisaris, leverage dan pengungkapan media terhadap pengungkapan CSR pada perusahaan yang listing dan go public di BEI khususnya untuk perusahaan-perusahaan sample hanya pada pencapaian angka 40,30 \% yang artinya komitmen perusahaan terhadap pengungkapan CSR masih belum bisa dikatakan cukup baik karena masih dibawah $50 \%$. Alasan yang bisa diberikan adalah adanya anggapan bahwa pengungkapan CSR bukan merupakan suatu keharusan yang dilakukan, atau melakukan praktik CSR dengan moto "yang penting ada" tanpa memperhatikan sustainability dari kegiatan yang telah dilakukan dengan kata lain perusahaan melakukan praktik CSR tanpa memperhatikan item-item yang telah tertuang didalam GRI 4 yang dijadikan pedoman didalam pelaksanaan nya. Hal ini bisa saja disebabkan karena perusahaan sample adalah termasuk perusahaan yang hanya melaksanakan kegiatan CSR secara sukarela tanpa ada kewajiban dan peraturan yang mengikat seperti yang tertuang dalam UU No. 40 Tahun 2007 dan PP RI No. 47 tahun 2012 karena aktivitas perusahaan-perusahaan sample tidak berinteraksi secara langsung dengan lingkungan sehingga tidak memberikan dampak yang negatif terhadap alam.

\section{SIMPULAN DAN SARAN}

\subsection{Simpulan}

1. Profitabilitas tidak berpengaruh terhadap pengungkapan CSR, hal ini dikarenakan manajemen perusahaan akan beranggapan bahwa kegiatan CSR hanya akan menambah biaya yang akan dikeluarkan sehingga akan mengurangi laba yang telah diperoleh perusahaan.

2. Ukuran perusahaan berpengaruh signifikan terhadap pengungkapan CSR. Hasil penelitian ini menggambarkan bahwa perusahaan-perusahaan 
sample dapat dikategorikan ke dalam perusahaan besar yang cenderung memiliki dampak sosial dan lingkungan yang lebih besar pula. Perusahaan besar akan lebih banyak melakukan pengungkapan CSR jika dibandingkan dengan perusahaan kecil, hal ini dikarenakan perusahaan besar merupakan emiten bisnis yang mempunyai tingkat visibilitas yang tinggi serta banyak disoroti oleh publik dan juga tidak akan lepas dari tekanan atas aktivitas operasional mereka. Perusahaan besar akan lebih responsive di dalam pelaksanaan kegiatan CSR sebagai bentuk tanggung jawab sosial dan lingkungan dengan maksud untuk menekan dampak buruk yang mampu mengganggu kelancaran dan kestabilan kegiatan operasional perusahaan.

3. Dewan komisaris berpengaruh signifikan terhadap pengungkapan CSR. Perusahaan besar biasanya mempunyai jumlah keanggotaan dewan komisaris yang banyak (komplit) sehingga akan lebih banyak pula melakukan pengungkapan CSR. Ukuran dewan komisaris yang besar didalam suatu perusahaan akan meningkatkan pengawasan terhadap kinerja direksi dalam mengelola perusahaan termasuk dalam praktik dan pengungkapan CSR. Dewan komisaris merupakan mekanisme dari Good Corporate Governance (GCG) yang berperan untuk meyakinkan bahwa perusahaan telah memenuhi keinginan para stakeholder untuk melaksanakan CSR.

4. Leverage berpengaruh signifikan terhadap pengungkapan CSR. Perusahaan akan menggunakan pengungkapan CSR sebagai sarana untuk membangun image yang baik untuk para debtholders, sehingga akan dianggap mampu untuk memenuhi kewajiban dalam membayar hutang dan kembali mendapatkan obligasi dimasa yang akan datang. Pengungkapan CSR akan memberikan nilai unggul dimana perusahaan yang melakukan kegiatan CSR akan lebih cenderung dijadikan mitra yang baik oleh para kreditur jika dibandingkan dengan perusahaan yang tidak dikenal karena orientasi sosialnya.

5. Pengungkapan media berpengaruh signifikan terhadap pengungkapan CSR. Media akan menjadi sarana yang penting untuk menyoroti dan mengabarkan berbagai kegiatan yang dilakukan oleh perusahaan, dalam hal ini termasuk juga pengungkapan kegiatan CSR yang telah dilakukan. Pengungkapan media dapat mendorong perusahaan untuk mengekspose aktivitas sosial dan lingkungan perusahaan sebagai bentuk etika bisnis terhadap publik sehingga dapat membangun image dan nilai sebagai perusahaan yang baik.

6. Secara simultan atau bersama-sama profitabilitas, ukuran perusahaan, dewan komisaris, leverage dan pengungkapan media berpengaruh signifikan terhadap pengungkapan CSR.

\subsection{Saran}

Berdasarkan hasil dari penelitian yang telah dilakukan. Maka terdapat beberapa hal yang perlu diperhatikan, yaitu:

1. Bagi peneliti selanjutnya

a. Penelitian ini dapat dijadikan acuan literatur bagi peneliti selanjutnya, para peneliti dapat menggunakan sustainability reporting yang telah di cross check oleh global reporting intiative, hal ini dilakukan untuk menghindari penilaian secara subjektif.

b. Untuk variabel pengungkapan media disarankan untuk melihat hanya dari website perusahaan saja melainkan dapat melihat dari majalah, koran maupun media televisi untuk mendapatkan hasil yang lebih akurat.

c. Penelitian selanjutnya diharapkan dapat menambah jumlah sample sehingga akan memberikan kemungkinan yang lebih besar untuk memperoleh kondisi yang sebenarnya.

d. Berdasarkan nilai $\mathrm{R}^{2}$ menunjukan persentase sejumlah 40,30\%, dalam artian tidak mencapai angka 50\% sehingga penelitian selanjutnya juga disarankan untuk menambah variabel penelitian yang lainnya untuk menemukan satu model yang standar pendugaan tentang pengungkapan CSR.

2. Bagi investor dan calon investor agar lebih seksama dalam memperhatikan aspek CSR perusahaan sebagai pertimbangan dalam melakukan investasi.

\section{DAFTAR REFERENSI}

Ayman, I. F. Issa. 2017. The Factors Influencing Corporate Social Responsibility Disclosure in the Kingdom of Saudi Arabia. Australian Journal of Basic and Applied Sciences 11(10) July 2017 Pages: 1-19.

Cahyani, Clara \& Suryaningsih, Rosita. 2016. The Effect of Leverage, Board of Commisioner, Foreign Ownership, Company Age, and Company Size Towards the Disclosure of Corporate Social Responsibility (CSR) Implementation. Accounting and Finance Review 1(1) page 27-33.

Crowther, David \& Aras, Guler. 2008. Corporate Social Responsibility. David Crowther, Guler Aras and Ventus Publishing Aps.

Coombs, W. Timothy \& Holladay, Sherry J. 2012. Managing Corporate Social Responsibility: A Communication Approach. Wiley-Blackwell: a John Wiley and Son Publication.

Dewanti, Ratna Listiana \& Widyadmono, V. Mardi. 2018. The Impact Of The Type of Industry, Company Size and Leverage on The Disclosure of Corporate Social Responsibility: Case on Companies Listed in Indonesia Stock Exchange 2009-2012. The international Journal of Social 
Science, Education and Human Science UTY Vol. 1 No. 1 January 2018 pp. 36-50.

Delena, Era. 2017. Praktek Pengungkapan Sosial Pada Laporan Tahunan Diperusahaan-Perusahaan Yang Terdaftar di PT. Bursa Efek Indonesia Pada Tahun 2016. Media Riset Akuntansi, Auditing, dan Informasi Vo.17 No.2 Sept 2017: 117-130.

Ehije, Ofanson Christoper \& Ofanson. 2013. The Effect of Firm Size and Profitability on Corporate Social Disclosures: Empirical Evidance From Nigeria. Journal.

Eriandani, Rizky \& Kuswanto, Christarina. 2016. Apakah Komposisi Dewan Direksi dan Dewan Komisaris Mempengaruhi Pengungkapan Corporate Social Responsibility (CSR)?. Ekspansi: Jurnal Ekonomi, Keuangan, Perbankan dan Akuntansi Vol.8 No.2 (November 2016) 213227.

Farman, Fanji. 2018. Influence Disclosure of Corporate Social Responsibility Againts Financial Performance. South East Asia Journal of Contemporary Business, Economics and Law Vol. 15 Issue 5.

Hargrave, Marshal. 12/4/2019. Return on Assets. Tersedia pada https://www.investopedia.com/terms/r/returnonass ets.asp. Diakses pada tanggal 13/3/2019

Irwansyah \& Ginting, Yoremia Lestari \& Kusumawardani, Anisa \& Erdiyanti, Juspita. 2018. Corporate Social Responsibility Disclosure, Leverage and Firm Value : The Moderating Role Of Profitability. Advance in Economics, Business and Management Research (AEBMR), Vol 35 : Research Gate.

Jenkins, Heledd \& Yakovleva, Natalia. 2006. Corporate Social Responsibility in The Mining Industry: Exploring Trends in Social and Environmental Disclosure. Journal of Cleaner Production Elsevier 14 (2006) page 271-284.

Kurnianingsih, Heni Triastuti. 2013. Pengaruh Profitabilitas Dan Size Perusahaan Terhadap Corporate Social Responsibility. Jurnal Riset Akuntansi dan Bisnis Vol.13 No.1/Maret 2013.

Keinert, Christina. 2008. Corporate Social Responsibility as an International Strategy. Physica-Verlag a Springer Company.

Laksmitaningrum, Chintya Fadila \& Purwanto, Agus. 2013. Analisis Pengaruh Karakteristik Perusahaan, Ukuran Dewan Komisaris dan Struktur Kepemilikan Terhadap Pengungkapan CSR : Studi Empiris Pada Perusahaan Manufaktur Yang Terdaftar di Bursa Efek Indonesia Tahun 2009-2011. Diponegoro Journal of Accounting Vol.2 No.3 Hal.1.

Lumbanrau, Raja Eben. 23/12/2016. Alfamart Gunakan Donasi Untuk CSR Perusahaan. Tersedia pada https://www.cnnindonesia.com/nasional/2016122 3121025-12-181730/putusan-kip-alfamartgunakan-donasi-untuk-csr-perusahaan. Diakses pada tanggal 8/2/2019.

Nur, Marzully \& Prinatinah, Denies. 2012. Analisis Faktor-Faktor Yang Mempengaruhi Pengungkapan Corporate Social Responsibility Di Indonesia (Studi Empiris Pada Perusahaan Berkategori High Profile Yang Listing di Bursa Efek Indonesia). Jurnal Nominal Vol. 1 No. 1.

Ompusunggu, Julius. 2016. The Effect of Profitability to the Disclosure of Corporate Social Responsibility (CSR Disclosure) on Mining Companies Listed on Indonesian Stockk Exchange (BEI) in The Year 2010-2012. IOSR Journal of Business and Management (IOSRJBM) Vol.18 Issue 6 Ver 1 (Jun. 2016) PP 69-78.

Putra, Idris Rusardi. 21/3/2017. Enaknya Freeport Keruk Emas Papua Tapi Tak Hargai Masyarakat Adat. Tersedia pada https://www.merdeka.com/uang/enaknya-freeportkeruk-emas-papua-tapi-tak-hargai-masyarakatadat.html. Diakses pada tangga 8/2/2019.

Restu, Muhammad \& Yuliandari, Willy Sri \& Nurbaiti, Annisa. 2017. Pengaruh Ukuran Dewan Komisaris, Proporsi Dewan Komisaris Independen dan Ukuran Komite Audit Terhadap Pengungkapan Corporate Social Responsibility. $e$ Proceesing of Management: Vol.4 No.3 Desember 2017/Page 27-42.

Reverte, Camelo. 2008. Determinants of Corporate Social Responsibility Disclosure Ratings by Spanish Listed Firm. Journal of Business Ethics: Springer 88 (2008) Page 351-266..

Suastha, Riva Dessthania. 21/7/2016. Riset Temukan Kualitas CSR Perusahaan Indonesia Rendah. Tersedia pada https://www.cnnindonesia.com/nasional/2016072 $\underline{1074144-20-146030 / \text { riset-temukan-kualitas-csr- }}$ perusahaan-indonesia-rendah. Diakses pada tanggal 5/2/2019.

Wagiu, Frily Ansyelia \& Mekel, Peggy A. 2014. The effect Of Firm Size, Profitability, Leverage, and Board Size On Disclosure of Corporate Social Responsibility in Company's Annual Reports. Jurnal EMBA Vol.2 No.3, September 2014 Hal. 15400-1549.

Wahyuningsih, Ana \& Mahdar, Nera Marinda. 2018. Pengaruh Size, Leverage dan Profitabilitas Terhadap Pengungkapan CSR Pada Perusahaan Manufaktur Yang Terdaftar di Bursa Efek Indonesia. Kalbis Socio: Jurnal Bisnis dan Komunikasi Vol.5 No.1 Februari 2018.

$\underline{\text { wWw.idx.co.id }}$

https://www.ojk.go.id/sustainable-finance/id/ Default.aspx 